\title{
Juridical Review of Interfaith Marriages and Its Legal Consequences Regarding Inheritance Sharing
}

\author{
Widodo Budidarmo ${ }^{1}$, Rineke Sara $^{2}$ \\ \{wbudidarmo@unis.ac.id ${ }^{1}$,rineke_sara@borobudur.ac.id² \\ Universitas Borobudur, Jakarta, Indonesia ${ }^{1,2}$
}

\begin{abstract}
This research is useful in understanding the legality of interfaith marriage in Indonesia under positive law, as well as the distribution of inheritance for married couples of various religions under Islamic law. This study uses a qualitative approach with normative legal research and analytical methods with literature studies. According to affirmative Indonesian law in article 2 paragraph (1) in combination with article 8 letter (f) of Legality No. 1 of 1974, the law of interfaith marriage is not permitted. Marriage is illegal between two persons in a relationship whose religion or other applicable restrictions prohibit them from marrying, according to the article. The partition of inheritance between husband and wife of various religions still permits married couples of different faiths to inherit from one of the spouses who died using a will, according to Islam.
\end{abstract}

Keywords: Interfaith Marriage; Islamic Law; Inheritance Rights

\section{Introduction}

Marriage is a significant and spiritual occasion in one's life. Marriage is related to the two prospective husbands and wife and involves family, community, and religious matters [1]. Every religion always connects marriage methods with spiritual principles so that marriage is generally considered sacred, and therefore all religions have textual marriage laws [2]. The marriage bond is an outward or physical bond and a spiritual bond based on God Almighty, meaning that marriage is not just an outward relationship, A link or an inside and exterior relationship between a man and a woman, but more than that. On the basis of the One Godhead, a man and a woman want to create a joyful and eternal family. Marriage is a sunnatullah that applies in general and the behavior of God's creatures. With marriage, life in this world can develop to enliven this vast universe from generation to generation [3].

Talking about valid marriage, in principle, will talk about the choice of a life partner who is genuinely from the most sincere heart even though in the selection there are many challenges, but for those who are genuinely convinced are those who want to formalize the bond in a valid marriage bond immediately [4]. Legitimate in the eyes of religion and state. "Marriage is an inner and outer relationship between a man and a woman as husband and wife to build a joyful and eternal family (home) based on the One Godhead," says Article 1 of Law Number 1 of 1974 on Marriage. 
Marriage and religion have a tight and inseparable link since religion is the basic base or foundation and is highly significant in domestic life.[5] Marriage is governed by all faiths, and every religion demands a marriage between a man and a woman of the same religion. Marriage based on the same religion and outlook on life will be happy for all time because the demands of religion last beyond the limits of human age, and the view of life will accompany humans throughout their lives [6]. With advances in technology today, human interaction can no longer be limited in a small and narrow society. Still, human relations have developed so rapidly with one another that they can penetrate the walls of their class, ethnicity, race, and religion [7]. One does not need to live in an area to recognize the culture or contact with indigenous people. Thanks to technological advances, one can interact between tribes, ethnicities, and religions [8]. The condition of social interaction as it is now is the basis for mixed marriages, whether inter-ethnic marriages, inter-ethnic marriages, inter-racial marriages, or even inter-religious marriages [1].

Mixed marriages that invite a lot of debate are inter-religious marriages. In inter-religious marriages, there will be a principal difference in marriage, so it is feared that problems that are difficult to resolve in the future, for example, regarding children. Human children have the most extended childhood, in contrast to flies that only need two hours or animals that only need about a month. Interfaith marriages will only cause problems, so many parties oppose interfaith marriages. For Muslims, after the issuance of Presidential Instruction Number 1 of 1991 concerning the Compilation of Islamic Law Article 44, mixed marriages of different religions, both Muslim men and non-Muslim women, have been completely prohibited. In addition, the Qur'an also expressly forbids the marriage of Muslim or Muslim women with Muslim men or women. These prohibitions are explicitly explained in the verses of the Qur'an in the letter al-Baqarah, Surah an-Nisaa, Surah al-Mumtahanah.

Marriage and religion have a strong and unbreakable bond. Almost all faiths have laws governing marriage, requiring that men and women of the same religion marry. This is reasonable because religion is the most important and essential factor in determining one's household's success. Interfaith marriages are no longer legal and are considered illegitimate by Law Number 1 of 1974. This marriage still occurs amid society, which is carried out secretly or openly by holding the wedding abroad. After that, it returns to Indonesia and registers at the Civil Registry Office as if the marriage is the same as the mixed marriage referred to. In Article 57 of the Marriage Law Number 1 of 1974. According to the provisions of Article 2 of Law Number 1 of 1974, it states that: "Marriage is legal if it is carried out according to the law of each religion and belief."

If you pay attention to Law Number 1 of 1974, no article regulates interfaith marriages. Even in Article 8, letter $\mathrm{f}$, it is stated that "Marriage is prohibited between two people who have a relationship whose religion or other regulations apply, it is forbidden to marry." Furthermore, Article 57 of Law Number 1 of 1974 regulates mixed marriages between two people, subject to two different laws. This article concerns differences in citizens and does not explicitly mention the existence of interfaith marriages. Besides being ready for conflict with their families, couples of different religions also need to discuss what religion they will teach their children. Marriage between two other brides is not a simple thing in Indonesia. In addition to going through social and cultural friction, the bureaucracy that must be passed is also complicated, so many couples with different beliefs finally choose to marry abroad. Couples who marry overseas will later get a marriage certificate from the country concerned or a local representative of the Republic of Indonesia (KBRI). After returning to Indonesia, they can register their marriage at the civil registry office to obtain a Certificate of Foreign Marriage Reporting. Not very difficult, but quite expensive. 
It does not mean that marriages with different religions cannot be realized in the country. Based on the Supreme Court's decision No. $1400 \mathrm{~K} / \mathrm{Pdt} / 1986$, couples of other faiths can request a court order. The jurisprudence states that the civil registry office may carry out interfaith marriages because the job of the civil registry office is to record, not ratify. However, not all civil registry offices are willing to accept interfaith marriages. The civil registry office ready to take interfaith marriages will later record the wedding as a non-Islamic marriage. Couples can still choose to marry according to their respective religious provisions. The trick is to look for religious leaders who have different perceptions and are willing to marry their partners according to their spiritual teachings, such as Islamic-style marriage contracts and Christian blessings. However, this method is tricky because it is rare for religious leaders and civil registry offices to marry couples of different faiths.

Marriage and inheritance law are two interrelated things because marriage is one of the causes of obtaining inheritance, and the marriage is mutually inherited between husband and wife. Interfaith marriages also have a relationship with the inheritance rights of each partner. The relationship between relatives of different religions in daily life is only limited to socializing and good relations. It is not included in the implementation of faith, such as inheritance law. In Islamic inheritance law, not all heirs can receive an inheritance because there are reasons that prevent the heir from getting an inheritance in Islamic inheritance law. The causes of inheritance barriers, meaning a situation that makes a person's opportunity to get an estate closed. As for the things that cause a person is not entitled to inherit the inheritance of the heir, namely: slavery, murder, different places (countries), religious differences, and because they disappeared without news.

Legacy is a subset of civil law and the smallest component of family law. Because every human being will experience a legal event termed death, inheritance law is directly tied to the extent of human existence. The problem of how to handle and continue the rights and duties of someone who dies arises as a legal consequence of the emergence of a legal possibility of someone's death. Inheritance law governs the distribution of rights and duties following a person's death. The distribution of inheritance or inheritance after the testator's death is a form of obligation because it is based on qat'i texts. That's the general rule of an estate. Muslims, in general, have been given explicit provisions so that they are expected to be easy to implement. Islamic law expressly prohibits Muslims from inheriting non-Muslims. Meanwhile, civil law does not emphasize the division of inheritance between husband and wife of different religions. In reality, married couples of different religions generally prefer to settle the distribution of their inheritance only through deliberation. Still, it cannot be denied that the distribution of estate for married couples of different religions causes a lot of conflicts, so they choose to settle it in Court.

\section{Methodology}

This research is library research, namely research that uses secondary data. The source of the data can be obtained through document search. Literature research is done by tracing the literature or data sources obtained from books, books, and others that directly or indirectly relate to this theme. Literature study is needed as a separate stage, namely preliminary research, to understand society's developing symptoms more deeply. In this regard, the purpose of this research is to describe the legitimacy of interfaith marriages under positive Indonesian legislation and to investigate the inheritance distribution for interfaith spouses under Islamic rule. 
This research approach uses a normative system, namely reviewing legal issues normatively (permissible or not according to applicable law). The research conducted is descriptive analysis, which systematically describes the facts on the problems that have been put forward to limit the study framework to comment or classification without directly aiming to test hypotheses or theories.

\section{Results and Discussion}

\subsection{According to Positive Indonesian Law, Interfaith Marriage is Legal}

Marriage law in Indonesia is contained in the Civil Code, For Muslims, Presidential Instruction No. 1 of 1991 about the Compilation of Islamic Law is more thorough than Marriage Law No. 1 of 1974. The Civil Code still corresponds to the Western legal notion, and Marriage Law No. 1 of 1974 refines it further. In Indonesia, the Marriage Law extends to all religions. The Marriage Law gives a very decisive role in determining the validity of marriage to the religious law and beliefs of each prospective bride and groom. This situation is seen in Article 2 of the Marriage Law, namely, "Marriage is legitimate as long as it is performed in accordance with each faith and belief." Following the 1945 Constitution, there is no marriage outside the law of his faith and belief, according to the explanation of Article 2 paragraph (1).

The interpretation of Article 2 is that for Muslims, there is no possibility to marry in violation of the laws of their religion. Likewise, for Christians and Hindus. Therefore, this is a dead-end for prospective brides of different faiths to carry out interfaith marriages. In addition to the regulations in Article 2, it is also impossible for them to use the mixed marriage regulations in Chapter XII, Article 57 of the Marriage Law, which does not regulate interreligious marriages. Observing the above provisions and their explanations, marriage is valid if carried out according to their respective religions.[9] A marriage whose terms and conditions are permitted by his religion, then his marriage is legal according to law. However, many also argue/interpret that the provisions of the Marriage Law No. 1 of 1974 Article 2 mean that marriage is permitted if carried out under religion and belief. Only God Almighty knows the conditions of religion and belief and absolute interpretation so that each individual can interpret according to his ideas. No institution or institution has a definitive understanding.

The ambiguity and ambiguity of the Marriage Law regarding inter-religious marriage in Article 2 is a statement according to the law of each religion or belief. This means that there is no difficulty if the union of the two prospective husbands and wives is the same. But suppose the religious law or belief is different, then in the case of a difference between the two religious laws or beliefs. In that case, all of them must be fulfilled, meaning once according to the sacred law or belief of the candidate and once according to the religious law or belief of the other candidate. The following is the law of interfaith marriage according to positive law in Indonesia.

\section{a) Law of Interfaith Marriage According to Islamic Law}

The Indonesian Ulema Council issued fatwas Number 05/Kep/Munas II/MUI/1980 dated June 1, 1980, and Number 4/Munas VII/MUI/8/2005 dated July 28, 2005, which addressed the issue of interfaith marriages. The fatwa contains two statements: a Muslim woman is not allowed (haram) to marry a non-Muslim man and the second, that a Muslim man is not 
permitted to marry a non-Muslim woman. Nahdlatul Ulama (NU) in Bahtsul Masail at the 28th Congress of Yogyakarta, stipulating a fatwa related to interfaith marriage, namely marriage of different religions is unlawful and invalid. The majority of scholars have decided that interfaith marriages are haraam and invalid [10].

The Qur'anic argument explains the marriage of two religions, namely QS. Al-Baqoroh: 221, which means "And do not marry the polytheists (to believing women) before they believe. Verily, believing slaves are better than polytheists, even though $\mathrm{He}$ attracts your heart. They invite them to hell". This is also confirmed in the word of Allah QS. Al-Mumtahanah: 10, which means "They (Muslim women) are not lawful for the non-Muslims and the nonMuslims are not lawful for them."

The MUI Fatwa and the two verses of the Koran above clearly explain the law of interfaith marriage. Muslim women are prohibited from marrying people who are not from the Islamic religion. God put the rules in marriage to keep away the breakdown and deadlock in the household. However, there is a verse in the Koran that allows a Muslim man to marry a woman from the people of the Bible. This is stated in the QS. Al-Maidah:5, which reads: "This day the good are made lawful for you. the food (slaughter) of those given the Book is lawful for you, and your food is lawful (too) for them. (And it is lawful to marry) women who guard honor among believing women and those who guard honor among those who were given the Bible before you, if you have paid their dowry to marry her, not with the intention of adultery and not (also) make her concubines. Whoever disbelieves after believing (does not accept the Islamic laws) then his deeds will be erased, and on the Day of Resurrection he will be among the losers."

In interfaith marriages in Islam, two schools provide views on this matter. The first stream states that interfaith marriages are possible. It's just that this can be done if the men are Muslim, while the women are non-Muslims (Al Maidah:5). If the condition is the other way around, then according to this school, interfaith marriages cannot be carried out (Al Baqarah: 221). On the other hand, the other sect states that in Islam, whatever the conditions, interfaith marriages cannot be carried out (Al-Baqarah: 221).

Although the Quran permits a Muslim man to marry a woman from the people of the Bible, the fatwa does not allow it. Because such marriages have more significant losses (mafsadah) than benefits (maslahah), we have already seen that religion is the main foundation for building a household. Still, if the family has two different foundations, it is feared that it will not be solid. The purpose of marriage is to build an eternal home. So that interfaith marriages have no advantages but disadvantages for the husband and wife and even the children they give birth to [11].

\section{b) Law of Interfaith Marriage According to Law Number 1 of 1974 Concerning Marriage}

With the enactment of Law Number 1 of 1974 concerning Marriage (Law on Marriage), all Dutch East Indies marriage laws are declared no longer valid. This is expressly stated in Article 66 of the Marriage Law. Marriage is an inner and outer relationship between a man and a woman as husband and wife to build a joyful and eternal family (home) based on the One Godhead, according to Article 1 of the Marriage Law. This article implies that marriage in Indonesia is marriage between a man and a woman only. Furthermore, According to Article 2 of the Law, a marriage is lawful if it is performed in accordance with the laws of the spouses' respective religions and beliefs. The marriage must also be recorded once it has been performed, in this case, at the Office of Religious Affairs and the Civil Registry. 
Article 6 of the Marriage Law stipulates several requirements for marriage, namely:

1. Marriage must be based on the consent of the bride and groom.

2. If the prospective bride and groom have not reached the age of 21 years, he must get permission from both parents or one of them if one of the parents has died or cannot express his will. Suppose both of them have been killed or are in a state of being unable to express their will. In that case, permission is obtained from the guardian, the person who maintains it, or a family who has blood relations in a straight line of descent as long as they are still alive and in a state of expressing their will.

3. Suppose there is a difference of opinion between the people mentioned above, or one or more of them do not express their opinion. In that case, the Court in the legal area of residence of the person who will enter into the marriage at that person's request may grant permission to marry.

4. The above provisions do not contradict or are not regulated otherwise by each religion and belief law.

Meanwhile, for the prohibition of marriage, the Marriage Law (Article 8) only in principle only prohibits the occurrence of marriages in which the two have a particular relationship, whether by blood, marriage, marriage, or relationships banned by their religion or other regulations. The Marriage Law views marriage not only from a purely formal aspect but also from a religious aspect. The religious aspect determines the validity of a marriage, while the formal part concerns the administrative element, namely the registration of marriages. According to the Marriage Law, both of these aspects must be met. If the wedding is only carried out according to the provisions of state law, without regard to religious elements, the marriage is considered invalid. On the other hand, marriage is carried out only by paying attention to aspects of religious law, without paying attention to or ignoring the law (state law), then the marriage is considered invalid.

\section{c) Interfaith Marriage Law According to the Compilation of Islamic Law}

The formulation of the Marriage Law states that there is no marriage outside the law of each religion and belief. The same thing is explained in several articles in the Presidential Instruction of the Republic of Indonesia Number 1 of 1991 concerning the Compilation of Islamic Law, as follows:

Article 4:

According to Islamic law, marriage is legal if carried out under article 2 paragraph (1) of Law no. 1 of 1974 concerning marriage.

Article 40:

It is forbidden to enter into a marriage between a man and a woman due to unavoidable circumstances;

1. Because the woman in question is still bound by one wedding to another man;

2. A woman who is still in the period of iddah with another man;

3. a non-Muslim woman.

Article 44:

A Muslim woman is prohibited from marrying a man who is not Muslim.

Article 61:

Not sekufu cannot be used as a reason to prevent the marriage, except not sekufu because of religious differences or ikhtilaf al-dien. 
Based on the explanation of several Articles of Compilation of Islamic Law above, marriages carried out in Indonesian jurisdictions must be carried out in one religious way, meaning that interfaith marriages are not allowed to be carried out. If they are forced to hold interfaith marriages, the marriage is invalid and violates the law. Pillars determine the validity or illegitimacy of a legal act or legal event. If one of the pillars in a permitted event or legal action is not fulfilled, it will result in the cancellation of a legal event or legal action. It can even result in the invalidation of a legal event or legal action. Likewise, according to the fiqh scholars, the pillars function as determinants of the legality or cancellation of a legal act.

Based on the explanation above, the writer can say that no explicit regulation of interfaith marriage in Law no. 1 of 1974 caused different interpretations of Article 2 paragraph (1) of Law no. 1 of 1974. This causes legal uncertainty for couples with interfaith marriages, while interfaith marriages in Indonesia cannot be avoided due to heterogeneous community conditions. The author argues that interfaith marriages are prohibited by Article 2 paragraph (1) and Article 8 letter (f) of Law No. 1 of 1974. Because it is stated in Article 8 letter (f) that marriage is banned between two persons who are in a relationship and are prohibited from marrying by their religion or other applicable legislation. It is clearly stated, "it is forbidden between two people who are prohibited by their religion." Marriage between a Muslim and a mushrik is not allowed either according to Islamic religious law or Article 8 letter (f) of Law Number 1 of 1974 concerning Marriage.

Since the enactment of the national marriage law in 1974, the Indonesian people, which are generally heterogeneous, are still confused by the fact that interfaith marriages are carried out by several people in this country because in the national marriage law that has been passed there is no regulation found. Which explicitly regulates or prohibits interfaith marriages. So it can be said to create a legal vacuum. There are two ways to deal with interfaith marriages: First, one of the parties can convert, but this can mean legal smuggling because what happened was only to legally circumvent the provisions of Law No. 1 of 1974 concerning Marriage. However, after the marriage took place, each party reverted to their respective religions. This method is not recommended. Second, the Civil Registry Office can hold interfaith marriages based on Supreme Court Decision No. 1400 K/Pdt/1986.

This case began with the marriage that Ani Vonny Gani P (female/Islamic) wanted to register with Petrus Hendrik Nelwan (male/Christian). The Supreme Court's decision stated that by submitting a marriage registration at the Civil Registry Office, Vonny had ignored the Islamic religious regulations regarding marriage. Therefore, he wanted his marriage not to be carried out according to the Islamic religion. Thus, if they are not Muslim, the Civil Registry Office must carry out the wedding. On a contrary basis, KUA is obliged to carry out their marriage because Christian women no longer care about their Christian status. Therefore, it is clear that the law is subject to all Islamic law related to marriage. Thus, from the beginning, couples of different religions do not need to smuggle the law by temporarily changing their faith, but they can get married without changing their religion.

Based on the comprehensive explanation above, it can be seen that interfaith marriages cannot be carried out because they violate Law No. 1 of 1974 concerning Marriage. Therefore, the Supreme Court Decision No. $1400 \mathrm{~K} / \mathrm{Pdt} / 1986$ has filled the legal void of interfaith marriages in the Marriage Law. And can be used as jurisprudence in the implementation of interfaith marriages. Still, morally if you look at the culture and religion in Indonesia, interfaith marriages will more or less become a polemic among the community and contribute to creating social friction in society because, in essence, marriage is considered sacred and sacred thing. The implementation and conditions of marriage must follow religious provisions. 


\subsection{Inheritance Distribution of Couples of Different Religions in the Light of Islamic Law}

Inheritance law governs the transfer of ownership rights to the testator's inheritance, establishing who is eligible to become heirs and how much of each they are entitled to. Marriage and inheritance law are two interrelated things because marriage is one of the causes of obtaining inheritance, and the marriage is mutually inherited between husband and wife. Interfaith marriages also have a relationship with the inheritance rights of each partner. The relationship between relatives of different religions in daily life is only limited to socializing and good relations. It is not included in the implementation of faith, such as inheritance law.

In Islamic inheritance law, not all heirs can receive an inheritance because there are reasons that prevent the heir from getting an inheritance in Islamic inheritance law. The causes of inheritance barriers, meaning a situation that makes a person's opportunity to get an estate closed. As for the things that cause a person not to be entitled to inherit the heir's inheritance, namely: slavery, murder, different places (countries), religious differences, and because they disappeared without news. In Islamic inheritance law, a person can be prevented from receiving an inheritance or becoming an heir due to religious differences, meaning that the heir's religion and the heir are different. "Muslims do not inherit the property of infidels, and unbelievers do not inherit the property of Muslims," according to a hadith attributed to the Prophet, Rowahu Buchori, and Muslims. However, in Islamic inheritance law, a will can still be used. The Compilation of Islamic Law declares in Articles 194 and 195:

Article 194

a. A individual which is at least 21 years of age, of mentally competent, and can bequest a portion of his wealth to that other individual or organization without force can do so.

b. The testator's entitlement to the willed property must exist.

c. According to Asaph (1) of this article, property ownership and rights can only be exercised once the testator dies.

Article 195

a. A will is made orally before two witnesses, or in writing before two witnesses, or before a notary.

b. A will is only allowed a maximum of one-third of the inheritance unless all heirs agree.

c. The will to the heirs is valid if all the heirs approve it.

d. The statement of approval in paragraphs (2) and (3) of this article is made orally before two witnesses or in writing before two witnesses before a Notary

According to Article 2 paragraph (1) of the Law of the Republic of Indonesia No. 1 of 1974 governing marriage, a lawful marriage is one that is performed in accordance with the laws of each religion and belief. As a result, the marriage legislation calls into question the legality of marriage from a theological standpoint. Interfaith marriages are forbidden in Indonesia by all religions. Although interfaith weddings are outlawed by all faiths, interfaith marriages are also prohibited by the marriage legislation, making them invalid under Indonesian law.

The consequences for husband and wife involved in inheritance are that there are no inheritance rights from people of different religions, so husband and wife from interfaith marriages can only inherit through wills, obligatory and gifts. So in interfaith marriages related to inheritance issues based on Article 195 of the Compilation of Islamic Law, interfaith couples can get an inheritance from one of their partners with a will which is made orally or in 
writing before two witnesses or before a Notary and is valid if approved by all heirs. The share amount is a maximum of one-third of the inheritance unless all the heirs agree. Thus the effect on husband and wife involved in heritage is that there are no inheritance rights from people of different religions, so that husband and wife from interfaith marriages can only inherit through wills, obligatory and gifts.

\section{Conclusion}

Based on the results of the analysis that has been carried out on the rigid laws in Indonesia related to interfaith marriages, it can be concluded as follows: Article 2 paragraph (1) jo of the positive Indonesian legislation prohibits interfaith marriage. Interfaith marriages are prohibited under Article 8 letter (f) of Law No. 1 of 1974. Because it is stated in Article 8 letter (f) that marriage is banned between two persons who are in a relationship and are prohibited from marrying by their religion or other applicable legislation. Interfaith marriage is outlawed by all faiths in Indonesia, and it is also prohibited by the marriage legislation, making it invalid under Indonesian law. In Islamic law, the partition of inheritance between husband and wife of different religions implies "Muslims do not inherit from infidels, and unbelievers do not inherit from Muslims," according to the Prophet Muhammad's hadith. However, in Islamic inheritance law, a married couple can still inherit from one of their deceased spouses by using a will in accordance with Articles 194 and 195 of the Compilation of Islamic Law.

\section{References}

[1] U. Hasanah, "Perempuan Dan Hak Asasi Manusia Dalam Perspektif Hukum Islam," J. Huk. Pembang., vol. 40, no. 4, p. 440, 2010, doi: 10.21143/jhp.vol40.no4.235.

[2] Y. I. F. Tuapattinaya and S. Hartati, "Pengambilan Keputusan Untuk Menikah Beda Etnis: Studi Fenomenologis Pada Perempuan Jawa,” J. Psikol. Undip, vol. 13, no. 1, pp. 34-41, 2014, doi: 10.14710/jpu.13.1.34-41.

[3] M. A. Nasir, "Religion, Law, and Identity: Contending Authorities on Interfaith Marriage in Lombok, Indonesia," Islam Christ. Relations, vol. 31, no. 2, pp. 131-150, 2020, doi: 10.1080/09596410.2020.1773618.

[4] H. Jawad and A. Elmali-Karakaya, "Interfaith Marriages in Islam from a Woman's Perspective: Turkish Women's Interfaith Marriage Practices in the United Kingdom," J. Muslim Minor. Aff., vol. 40, no. 1, pp. 128-147, 2020, doi: 10.1080/13602004.2020.1737415.

[5] E. E. Supriyanto, "Kontribusi Pendidikan Pesantren Bagi Pendidikan Karakter di Indonesia,” J. Pendidik. Nusant., vol. 1, no. 1, pp. 13-26, 2020.

[6] J. Van Niekerk and M. Verkuyten, "Interfaith marriage attitudes in Muslim majority countries: A multilevel approach,” Int. J. Psychol. Relig., vol. 28, no. 4, pp. 257-270, 2018, doi: 10.1080/10508619.2018.1517015.

[7] A. Wardatun, F. Syariah, U. Islam, and N. Mataran, "Legitimasi Berlapis dan Negosiasi Dinamis pada Pembayaran Perkawinan Perspektif Pluralisme Hukum Pendahuluan Islam, adat, dan negara adalah tiga aspek yang sangat berkaitan di dalam saling menegasikan . Ada banyak aspek dalam hukum keluarga di mana huku," $A l$ Ahkam, vol. 28, no. 2, pp. 147-166, 2018. 
[8] M. Mahsun, "Rekonstruksi Pemikiran Hukum Islam Melalui Integrasi Metode Klasik Dengan Metode Saintifik Modern,” Al-Ahkam, vol. 1, no. 25, p. 1, 2015, doi: 10.21580/ahkam.2015.1.25.191.

[9] S. Bhatoo and U. Bhowon, "Voices of Young Women in Interfaith Marriages," Asian J. Soc. Sci., vol. 46, no. 3, pp. 281-303, 2018, doi: 10.1163/15685314-04603004.

[10] M. T. Rahman, "Perkawinan Beda Agama Menurut Ormas Islam di Indonesia (Studi Fatwa NU dan Muhammadiyah)," 2018.

[11] F. Kurttekin, "Religious education of children in interfaith marriages," J. Beliefs Values, vol. 41, no. 3, pp. 272-283, 2020, doi: 10.1080/13617672.2019.1624938. 